\title{
Testing the Effectiveness of "English Language" Course Book for Indonesian Senior High School Students
}

\author{
Risma Rasyid, Novalia Tanasy, and A. Muhajir Nasir \\ Universitas Muslim Maros, Turikale, Indonesia \\ rismarasyid@gmail.com
}

\section{ARTICLE HISTORY \\ Received : 29 August 2019 \\ Revised : 3 September 2019 \\ Accepted : 4 October 2019}

\section{KEYWORDS}

English Course Book

English Language

High School Education

Effectiveness

\begin{abstract}
English as an international language is one of the general subjects taught at school. Many school apply English as subject. From the explanation which has been explained above the researcher was research about course book. This study aims to know the effectiveness of the English course book by pre-experimental method with giving the students pre-test and post-test. The researcher conducted the first grade students in the senior high school in Maros specially at MA DDI Alliritengae Maros. The results show that learning outcomes after using the English Couse Book titled "English Language", it can be seen that the average value is 66.42 and the classical completeness is $15.79 \%$. Where, the average learning outcomes are still less than 75 and the classical completeness is still less than $75 \%$. So it can be said that the learning outcomes also do not meet the Minimum Completeness Criteria (KKM) specified. In conclusion, learning using the English Course Book titled "English Language" is not effective to be applied in class X.1 IPA MA. DDI Alliritengae Maros.
\end{abstract}

\section{Introduction}

English as an international language is one of the general subjects taught at school. Many school apply English as subject. English language become the foreign language to student to support and motivate the students in order to make them ready and confident in learning English at higher levels. This accordance with the function of English lesson by education department and Culture. The function of the English lesson is to introduce English as the first foreign language to students. Meanwhile, the objectives are to motivate and to support the students in order to make them ready and confident in learning English at higher levels, Education Department and Culture (1995:1). It means that the sooner someone learning English is better, but to motivate them to get ready is better at higher level.

English language is not easy. Many students get some problems to learn it so the teachers feel difficult to teach English too (Budiarti et al., 2019). The challenge is if students can't make the right sounds because their pronunciation in foreign languages is influenced by their first language (Ariati, 2020). Especially, now the curriculum has change to a new curriculum, namely curriculum 2013. The Minister of Education and Culture of Indonesia, (in Nuh, 2013) said that the future of this nation depends on the new curriculum. According to his quotation, it is obvious that without changing the curriculum, there will be no progress. Because that issue, Indonesian government officials, especially those in educational sphere, sat together to elaborate the currently implemented curriculum. All corresponding teaching or learning materials, its corresponding programs, course books, without putting aside how that curriculum is going to be implemented.

The change of curriculum is one of the factors which make the students experience difficulties in the learning process. It is related to the condition of the students who face difficulties to understand the material of a course book, and the language level that used is high too. It can't improve the students' knowledge. For example, they tend to say "what is definition of this word, or this sentences?" as a evidence from no understanding of students. Using language in the course book should be easy to understand and to teach in learning process. Therefore, the senior high school English teacher have to be able to select method to obtain the success of the English teaching learning process to achieve learning objectives.

From the explanation which has been explained above the researcher was research about course book. The researcher was conduct a research in relation to know the effectiveness of the English course book by preexperimental method with giving the students pre-test and post-test. Pre-test before using the course book and post-test after using the course book to measure of the effectiveness of course book. The researcher was be conducted the first grade students in the senior high school in Maros specially at MA DDI Alliritengae Maros. 


\section{Literature Review}

Evaluating the effectiveness of a course book is not a simple task. A course book will be effective when it has achieved its intended objectives or goals. Regarding to the definition of effectiveness, Cambridge Advanced Learner's Dictionary (2000) gives an understandable definition. It states that something is effective when it is successful or achieving the results that you want. Oxford Dictionary (in Irambona, 2015) embraces the same idea that "effectiveness is the degree to which something is successful in producing a desired result; success". In the same way, it can be understood that effectiveness is the degree to which objectives are achieved learning objectives and the extent to which targeted problems are solved (Edam, Pangemanan, \& Kairupan, 2018).

Objectives are needed to identify the expected outcomes, to suggest directions, and to determine the means of evaluation. If one tries to analyze the different definitions given, he or she can draw a conclusion that through objectives, the effectiveness of a course book can be deduced from there. In educational institutions, a course book will be claimed as being effective in case the stated objectives have met the needs of the students.

The conceptual framework this research is given in the following diagram:

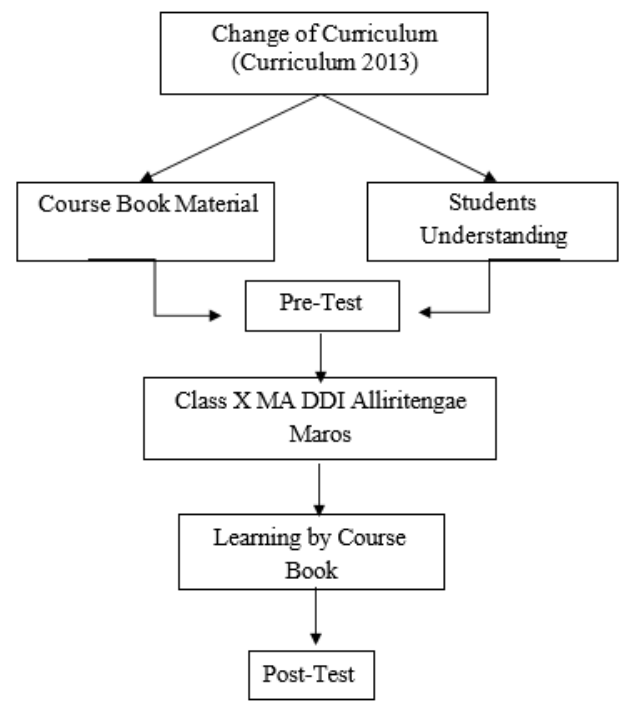

Figure 1. Conceptual Framework

A course book or textbook, a book designed to accompany a specific academic course, or one specified by the writers of the course to be read by its students. A course book is a textbook that students and teachers use as the basis of a course. A course book is actually a book which contains material or content that will be used in the teaching learning process in classroom. According to BSNP (in Indrawati, 2012:19) "states that a course book is the written products that provide the knowledge of the author".
Course book are one of the most important learning tools and strategic to determine success in the learning process of students in school and at home. From textbooks that we can get various information and knowledge (Wardani, 2010). Therefore (BSNP, 2006: 147) states that the worthiness of a course book that can be used in the learning proses includes from content eligibility, language, presentation, graphic textbooks, which has been assessed by BSNP and determined by ministerial regulation.

Based on the above understanding the researcher conclude, the use of course book must be based on the curriculum to achieve the learning objectives that have been made previously. Which aims to make it easier for students to understand the material from the course book.

\section{Method}

\subsection{Type of Research}

Type of the research is quantitative research. The research design used was Pre-Experimental type one-group pretest-posttest design. Sugiyono (2014, p. 109) states that the pre-experimental design "... happened because absence of control variables, and samples that were not randomly selected ". Because this research was conducted by using experiment class without any control group, and began with the provision of pre-measures to measure initial ability of the subject. Furthermore, the sample give treatment, namely the use of course book by the teacher to students. Then the subject was given posttest to measure the ability of the sample after being treated.

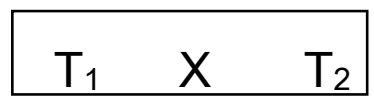

Figure 2. Table of Research Design, Pre Experimental Design

Information:

T1 : Preliminary test before treatment

T2 : Final Test after treatment

$\mathrm{X}$ : Treatment with course book

In this study, the class was given a pretest to find out the initial conditions of the ability of learning outcomes before treatment, then the class was treated with course book. Furthermore, they were given a posttest after being treated to find out whether there are any changes to student learning outcomes. The following is design research design.

Table 1. The design of the One Group Pretest-posttest Design

\begin{tabular}{cccc}
\hline Group & Test & Treatment & Test \\
\hline \multirow{2}{*}{ Class X1 } & Pretest & $\begin{array}{c}\text { Learning with } \\
\text { Course book }\end{array}$ & Posttest \\
& & $\underline{ }$ & \\
\hline
\end{tabular}




\subsection{Place and Time of the Research}

This research was conducted at MA DDI Alliritengae Maros JL. Taqwa No.2 Maros, Alliritengae village, Turikale sub-district, Maros Regency, South Sulawesi Province. And this research was conducted for 5 months. Then the researcher spent about 2 months to analyze the data.

\subsection{Population and Sample}

Population in the research were MA DDI Allirtengae Maros and the sample of the research are the first grade students or X.1 MA DDI Alliritengae Maros.

\subsection{Variable}

This research use two variables. The independent variable of the research is he effectiveness of English course book. The dependent variable of the research is the first grade students at MA DDI Alliritengae Maros.

\subsection{Research Hypothesis}

A hypothesis is a tentative answer the problem of the research, the hypothesis, they are:

a) Null Hypothesis (Ho):

There is no a significant achievement after implementing the course book entitled "English Language".

b) Alternative hypothesis (Ha):

Effectiveness of students' achievement in their understanding of English after applying a course book entitled "English Language".

\subsection{Technique Data Collection}

The technique data collection of the research is through tests (pre-test and post-test). To measure the ability of students' understanding of English, one of which is view from the results of English tests. Written tests was conducted by using second semester English questions included in class X semester II material, which is related to the announcement material, and other material in subsequent chapters in the second semester course book. This test was using 25 items in multiple choice test.

\subsection{Research Instruments}

The research instruments used in this research are:

a) Test

The tests is a data collection tool in the form of questions that are used to obtain score as a measurement of research. In this study, researcher used descriptive questions to determine students create thinking abilities. Before the written test questions are used, first the researcher try to ensure the validity and reliability of the test questions.

b) Validity Test
The validity of a test can be divided into two types namely logical validity and empirical validity. To find out the level of validity of the test questions in the form of description questions that will be used to retrieve data, research uses logical validity and empirical validity.

In this study, researcher was used logical validity in the form of content validity, that is testing of validity carried out on its contents to certain whether the items of student learning outcomes test accurately measured the circumstances that wanted to be measured. Content validation testing can be done by asking for expert judgment. People who have competence in an area can be asked for their opinions to assess the accuracy of the contents of test items in students English creative thinking.

\subsection{Technique of Data Analysis}

Effectiveness of course book is collected though the provision of test. Tests was giving 2 times, namely before the learning process takes place or pretest and after the learning process or posttest. The test give is a validated test after the data is collected then it is analysis techniques. Data obtained from the results of the study was analyzed though the SPSS (Statistical Package for Social Science) that has a high ability with data management and operation that is quite simple. To analyze the data, the researcher used two kinds of statistical techniques and inferential statistics.

\section{a) Descriptive Statistics}

Descriptive statistics are used to describe the characteristics of respondents, among others in the form of averages and standard deviations of respondents both before and after treatment is given. In addition to describe student learning outcomes, this research described how the difference occur after students are gave treatment. The difference was reviewed based on the calculation of the normalized gain value. Normalized gain value in this research be obtain by diving the gain score (the differences between the posttest and the pretest) by the differences between the maximum score and the pretest score. The calculation of normalized Gain Value Hake (In Sari, 2018). Following formula as follow:

$$
\begin{aligned}
& \mathrm{G}=\mathrm{O}_{2}-\mathrm{O}_{1} \\
& \langle\mathrm{~g}\rangle=\frac{\mathrm{O}_{2}-\mathrm{O}_{1}}{\mathrm{SM}-\mathrm{O}}
\end{aligned}
$$

The formula is used to calculate the normalized gain of the differences that occur in English achievement of students in the material from second semester of course book is used and series with the following information:

$$
\begin{array}{ll}
\mathrm{G} & =\text { Gain (difference) } \\
\mathrm{<g}> & =\text { Normalized gain } \\
\mathrm{O} 1 & =\text { Pretest score } \\
\mathrm{O} 2 & =\text { Posttest score } \\
\mathrm{SM} & =\text { Maximum score }
\end{array}
$$

The normal gain score be obtaining was interpreted to state the criteria for the increase that occurs and as a 
variable data that will be used in testing the research hypothesis. The reference to the gain criteria that have been normalized according to Hake, are presented in the table below:

Table 2. Normalized Gain Category (Sari, 2018)

\begin{tabular}{cc}
\hline Interval & Category \\
\hline$<\mathrm{g}>>0,70$ & High \\
$0,30<<\mathrm{g}><0,70$ & Medium \\
$<\mathrm{g}>\leq 0,30$ & Low
\end{tabular}

\section{b) Inferential Statictics}

Inferential statistics are used to test research hypotheses. In this research the One Sample T-test statistical analysis used to test the research hypotheses. But before testing the hypotheses, the prerequisite test is performed first. The prerequisite tests that carry out before testing this hypothesis the normality test score of normalized gain data in ability students.

Normality test is intended to find out whether the data study is from populations that are normally distributed or not. In this study for the normality test the SPSS program is used whit the following procedure.

c) Hypotheses

H0 : sample from populations that are normally distributed

H1 : sample from populations that are not normally distributed

d) Test Statistics

The significance level $(\alpha)$ is a number that indicates an analysis error. The significance level in this study was $5 \%$ or 0.05

\section{e) Test Decision}

$\mathrm{HO}$ is accept if the sign value in the Shapiro-Wilk test is more than the alpha level that has been determined ( $\mathrm{p}$ value $>\alpha=0,05)$

\section{f) Conclusion}

After analyzing the data using by the SPSS program, we have got to pay attention to significant value at KolmogrovSmirnov column and then compare it with significant 0.05 . If the significant value ( $\mathrm{Sig})>0,05$, then the data have a normal distribution, but if the significant value is (Sig) $<0,05$ then the data is not normally distributed.

The source of data in this study is the test results of students. the type of data to be obtained is quantitative data that is taken from the test of learning outcomes in the form of essays with some questions. Data collection method in this research is learning outcomes data which will be taken by giving tests to students before and after learning.

\section{Results}

This research was conducted at the MA. DDI Alliritengae Maros at class X.1 IPA with a total of 19 students. The study was conducted to determine the increase in student learning outcomes were given treatment that is using an English course book titled "English Language" in the experimental class. The results of this study describe the learning outcomes of students before and after using the English Course book.

This research was conducted from 28th of April to 11th of June, 2020 with 2 meetings, namely $45 \times 2$ minutes. Namely 2 times giving tests to students. The type of test given is a multiple choice test with 25 items that have been validated. From the provision of these tests obtained value of student learning outcomes.

\subsection{Description of Learning Outcomes Data Before Using the English Course Book}

To determine the initial state of learning outcomes of students in class XI.5 IPA MA. DDI Alliritengae Maros performed a pretest before using the English course book. The following are the results of the descriptive analysis results from the pretest data in class X.1 IPA MA. DDI Alliritengane Maros using the application of Statistical Product and Service Solutions (SPSS) version 16 and to find a general description of the pretest data displayed in Table 3:

Table 3. Summary of Pretest Learning Outcomes

\begin{tabular}{cc} 
Category & Pre Test \\
Number of sample & 19 \\
The Lowest Score & 34 \\
The Highest Score & 64 \\
Mean & 49,58 \\
Median & 52 \\
Range & 30 \\
Standard Deviation & 10,17 \\
Variance & 103,37 \\
\hline
\end{tabular}

From table 3, we can see that the lowest score of student learning outcomes before being taught with an English Course Book is 34 and the highest score is 64, while the average grade is 49.58 . Based on the description of student learning outcomes above, the pretest results are still in the low category. The categories of student learning outcomes can be seen as follows:

Table 4. Frequency and Percentage of Pretest Learning

\begin{tabular}{cccc}
\hline Value Interval & Frequency & Percentage $(\%)$ & Criteria \\
\hline Score $<40$ & 5 & 26,31 & Very Low
\end{tabular}




$\begin{array}{cccc}40 \leq \text { score }<55 & 7 & 36,84 & \text { Low } \\ 55 \leq \text { score }<75 & 7 & 36,84 & \text { Medium } \\ 75 \leq \text { score }<85 & 0 & 0,00 & \text { High } \\ 85 \leq \text { score } 100 & 0 & 0,00 & \text { Very High } \\ \text { Total } & 19 & 100 & \end{array}$

From table 4, we can see that the average value obtained by students is in the low category, the results above show that out of 19 students there are 5 people who score very low and there are 7 students who get low scores and 7 people in the medium category.

\subsection{Learning Outcomes After the Application of the English Course Book Entitled "English Language"}

To determine the final state of learning outcomes of students in class X.1 IPA MA. DDI Alliritengae Maros performed posttest. The following are the values and results of the descriptive analysis of the posttest data in class X.1 IPA MA.DDI Alliritengae Maros using the help of the application version of Statistical Product and Service Solutions (SPSS) version 16 and to find a general description of the posttest data displayed in Table 5:

Table 5. Recapitulation of Posttest Learning Outcomes

\begin{tabular}{cc}
\hline Category & Post Test \\
\hline Number Of Sample & 19 \\
The Lowest Score & 50 \\
The Highest Score & 92 \\
Mean & 66,42 \\
Median & 64 \\
Range & 42 \\
Standard Deviation & 9,20 \\
Variance & 84,70
\end{tabular}

In table 5 , it can be seen that the lowest score of student learning outcomes after being taught by using the English Course Book is 50 and the highest score is 92, while the class average is 66.42 based on the learning outcomes criteria is in the medium category. Based on the description of learning outcomes of students above on the posttest results are still in the medium category. The categories of student learning outcomes can be seen as follows:

Table 7. Frequency and Percentage of Posttest Learning Outcomes

\begin{tabular}{cccc}
\hline $\begin{array}{c}\text { Interval } \\
\text { Score }\end{array}$ & Frequency & Percentage $(\%)$ & Criteria \\
\hline Score $<40$ & 0 & 0,00 & Very Low
\end{tabular}

$\begin{array}{cccc}\begin{array}{c}40 \\ \begin{array}{c}\text { score } \\ 55\end{array}\end{array} & 1 & 5,26 & \text { Low } \\ \begin{array}{c}55 \leq \text { score }< \\ 75\end{array} & 15 & 78,94 & \text { Medium } \\ 75 \leq \text { score } 85 & 2 & 10,52 & \text { High } \\ \begin{array}{c}85 \leq \text { score } \\ 100\end{array} & 1 & 5,27 & \text { Very High } \\ \text { Total } & 19 & 100 & \\ & & & \end{array}$

In table 7 it can be seen that the average value obtained by students is in the medium category, from the results above it shows that out of 19 students there are 15 people who get a moderate score while students in the high category are only 2 people and so are the students in the very high category only 1 person anyway.

\subsection{Effectiveness of the English Course Book Entitled "English Language"}

Based on the description of student learning outcomes both pretest and posttest, the learning outcomes of students after being taught by using the English Course Book in the experimental class we can say that there is no significant improvement. In other words, the learning outcomes of students after being treated are different from the learning outcomes of students before being treated, but there are only small differences that do not have significant changes. This difference does not indicate an increase in student learning outcomes.

As for mastery learning students based on the rules set in the MA. DDI Alliritengae Maros in class X.1 IPA, students are said to be complete in English subjects if they reach a minimum mastery value of 75 . After students are taught using the English course Book there are only 3 students of 19 students who can achieve completeness, or in other words students' learning completeness achieved in the experimental class was $15.79 \%$.

Next, to illustrate the improvement that occurs after students are taught using an English course book, researcher have analyzed the normalized gain score shown in Table 8:

Table 8. Gain Normalized Student Learning Outcomes

Min Max Mean Variance Std.Deviation

Score Gain

$\begin{array}{lllll}0,09 & 0,78 & 0,33 & 0,03 & 0,18\end{array}$

\section{Normalized}

Table 8 shows that the average normalized gain of student learning outcomes is 0.33 . Based on the normalized gain category in table 3 shows that the average normalized gain is at a low criterion. That is, classically the learning 
outcomes of students after being taught with the English Course Book titled "English Language" has not increased.

\subsection{Inferential Analysis}

\subsubsection{Prerequisite Test Results Analysis of Research Results}

As explained in chapter III, inferential statistics are used to draw conclusions from the data obtained. In this case, inferential statistics are used to determine whether there is a significant increase in student learning outcomes in class X.1 IPA MA. DDI Alliritengae Maros has learned to use the English Course Book entitled "English Language". The inferential statistical test used in this study is the One Sample T-Test. However, before conducting the test, a prerequisite test is needed.

The prerequisite test used in analyzing the results of this study is the normality test, where the normality test is used to find out the data used comes from populations that are normally distributed or not. The data normality test used in this study was carried out with the help of the SPSS 16 application program. Data is normally distributed if the $\rho$ value in the Shapiro-Wilk test is more than alpha $(\alpha)$.

With a Hypothesis:

H0: Data comes from populations that are normally distributed.

H1: Data come from populations that are not normally distributed.

Test Rules:

$\mathrm{HO}$ is accepted, if : Sig. score $>0.05 \mathrm{HO}$ is rejected, if : Sig. score $<0.05$

The results of the computation of normality data testing are complete in the attachment Test of Normality section. A summary of the results is in Table 9:

Table 9. Normality Test Results

\begin{tabular}{lllll}
\hline Source & Sig. & $\alpha$ & Decision & Conclusion \\
& & & & \\
\hline Gain & 0.078 & 0.05 & Sig. $>\alpha$ & Normal
\end{tabular}

\section{Normalized}

Based on the results of the normality test above, the value of Sig. in the Shapiro-Wilk test is more than 0.05 so that it can be concluded that the data in this study come from populations that are normally distributed.

\subsubsection{Hypothesis Testing Results}

Hypothesis testing in this study used one sample t-test on normalized gain data. The t-test in this study was used to determine the effectiveness of the English Course book after it was used by students.

With a Hypothesis:
H0 : There was no significant increase in the learning outcomes of students in class X.1 IPA MA. DDI Alliritengae Maros after being taught using the English Course Book Entitled "English Language".

H1 : There is a significant increase in the learning outcomes of students in class X.1 IPA MA. DDI Alliritengae Maros after being taught using the English Course Book titled "English Language".

The statistical hypothesis is:

$$
\mathrm{H}_{0} \quad: \mu \overline{\mathrm{g}} \leq 0.30 \quad \text { Versus } \quad \mathrm{H}_{1} \quad: \mu \overline{\mathrm{g}}>0.30
$$

Test Rules:

$$
\begin{aligned}
& \mathrm{H}_{0} \text { is accepted, if }: \frac{1}{2} \alpha \leq \mathrm{Sig} \\
& \mathrm{H}_{0} \text { is rejected, if }: \frac{1}{2} \alpha>\mathrm{Sig}
\end{aligned}
$$

The results of computing this test are done with the help of the SPSS 16 application can be seen in the attachment. A summary of the results is presented in Table 10:

Table 10. One Sample T-Test

\begin{tabular}{l} 
Source $\begin{array}{c}\text { t-hitung } \\
\text { Sig.(2 tailed) }\end{array}$ Decision \\
\hline Gain $0.665 \quad 0.514 \quad \mathrm{H}_{0}$ is accepted \\
Normalized \\
\hline Based on the summary of the results of the data analysis \\
in table 10, obtained t-value $=0.665$ with the Sig. ( 2 tailed) \\
$=0.514 \geq 1 \alpha=0.025,2$ then according to the decision- \\
making criteria for hypothesis testing it can be concluded \\
that H0 is accepted. This means that there is no significant \\
effectiveness on the learning outcomes of students in Class \\
X.1 IPA MA. DDI Alliritengae Maros after being taught \\
with the English Course Book Entitled "English Language".
\end{tabular}

\section{Discussion}

In this section the researcher explains more about the results of testing descriptive statistics and inferential statistics on student learning outcomes data obtained from research.

The application of English Course Book gives a little positive influence on student learning outcomes. The effect can be explained by the average value of the test of learning outcomes measured through the pre-test before students learn the English Course Book and the final test (post-test) after students learn to use the English Course Book.

The average value of students in the pre-test is 49.58 , based on the description of the learning outcomes of students in the pretest results are still in this low category because of the ignorance of students about the material provided. Then the average value increased to 66.42 at the 
end of the post-test learning based on the criteria of learning outcomes in the medium category. One of the factors causing student learning outcomes to increase slightly, not significantly increasing due to changes in the curriculum that prevails in schools, namely the 2013 curriculum, the book follows the applicable curriculum and the material being taught is also more difficult, as well as learning conducted at schools nowadays are online based, where students only learn from home and teachers taught from home (WFH) So that students do not understand the material provided by the teacher.

What's more students are given training using online the material has also been presented online. This results in students who have constraints on internet quotas and students who have limited network at home paying less attention to learning and not understanding the learning provided by the teacher and unable to access the learning provided. So students are less active in learning activities, both asking questions and answering and expressing their opinions about the knowledge they have learned. The posttest also showed that there were only 3 out of 19 students or in other words $15.79 \%$ of students achieved the minimum mastery criteria (KKM) for English subjects in the MA. DDI Alliritengae Maros is 75.

In addition, inferential analysis also shows the fact that the One Sample T-Test with a significant level $\alpha=0.05$, obtained Sig (2-tailed) value of 0.514. Because Sig (2tailed) $\geq 12 \alpha$ or 0.025 , according to the rules of testing this hypothesis it is known that there is no significant increase in the learning outcomes of students in class X.1 IPA MA. DDI Alliritengae Maros after being taught using the English Course Book Entitled "English Language". There is no significant effectiveness of student learning outcomes can also be seen through the parameters of the average value of normalized gain student learning outcomes are distributed to the criteria of being. It does not show a significant effectiveness on student learning outcomes after being taught using the English Course Book titled "English Language".

Learning using the English Course Book titled "English Language" aims to determine the effectiveness of the English Course Book on students, especially class X.1 IPA MA. DDI Alliritengae Maros.

When the book is applied in learning, students enthusiastically ask, but when the teacher explains the material from the book and answers questions from students, students have difficulty understanding the material and it is difficult to understand the answer. The improve of students' outcomes of learning or the minimum completeness standards (KKM) achievement is one form of learning objectives achievement (Aswad et al., 2019). But the fact, it can be seen when the student's post-test score shows a value below the maximum completeness average (KKM) of 75 .
This is consistent with the opinion of Linda Rahmawati (2018) in her study entitled Content Analysis of the English Textbook Entitled "Primary English as a Second Language" said that this book is a good English book but for practice in the textbook it does not fit the criteria of a good English textbook because it is not paired with a partner / work group and must be corrected later. Then in the aspect of vocabulary also does not meet the criteria of a good English textbook because of the 25 chapters there are ten chapters that do not present new vocabulary in the next material. However, some of what is missing in a textbook can be improved by providing supplementary material while teaching certain material.

And in the research Teguh Ariebowo, entitled "The Evaluation of The Seven-Grade English Textbook When English Rings The Ball: A Survey Research". In the results of his research, researcher see that the textbook has advantages and disadvantages. The topic presented is a strength of this textbook given that the topic presented is suitable for the level of learning and social conditions of the Indonesian people. However, this textbook is not immune from deficiencies as in other books. One of the obvious shortcomings of this textbook is that there is no grammar reference that can be used as a reference by students and the level of difficulty of the language used in this book is too easy for 7 th grade junior high school students.

Based on the description above it can be concluded that not all books are effectively applied to students. As in this study, that the course book entitled "English Language" does not give effectiveness to students is proven by the average value obtained by students below the Maximum Completeness Criteria (KKM) value of 75.

\section{Conclusion}

Learning outcomes before using the English Course Book titled "English Language" showed that the average value was 49.58 and the classical completeness was $0.00 \%$. Where, the average learning outcomes were less than 75 and the classical completeness has not reached $75 \%$. So it can be said that the results of the study have not fulfilled the Minimum Completeness Criteria (KKM) specification. Learning outcomes after using the English Couse Book titled "English Language", it can be seen that the average value is 66.42 and the classical completeness is $15.79 \%$. Where, the average learning outcomes are still less than 75 and the classical completeness is still less than $75 \%$. So it can be said that the learning outcomes also do not meet the Minimum Completeness Criteria (KKM) specified. Learning using the English Course Book titled "English Language" is not effective to be applied in class X.1 IPA MA. DDI Alliritengae Maros.

This conclusion is based on the findings showing that $15.79 \%$ students achieve classical mastery learning, the average normalized gain of student learning outcomes is 0.33 or categorized as low category, and the value of the results of the analysis of one sample t-test obtained t-count 
$=0.665$ with the Sig. $(2$ tailed $)=0.514 \geq 1 \alpha=0.025$ so that there was no significant increase in the learning outcomes of Class X.1 IPA MA. DDI Alliritengae Maros after being taught using the English Course Book titled "English Language". From these three findings, it can be said that the learning outcomes of students after being taught by using the English Course Book titled "English Language" is not effective against the learning outcomes of students in class X.1 IPA MA. DDI Alliritengae Maros.

\section{References}

Ali Khan, S. (2005). Filsafat Pendidikan AlGhazali. Bandung: Pustaka Setia.

Alwasilah, A. C. (1997). Politik bahasa dan pendidikan. Remaja Rosdakarya.

Ariati, J. (2020). Analysing Reading Skill in National Plus School Curriculum: Phonological Awareness of Young Learners. REiLA: Journal of Research and Innovation in Language, 2(2), 70-75.

Aswad, M., Rahman, F., Said, I. M., Hamuddin, B., \& Nurchalis, N. F. (2019). A Software to Increase English Learning Outcomes: An Acceleration Model of English as the Second Language. The Asian EFL Journal. 26.(6.2), 157, 169.

Badan Standar Nasional Pendidikan. (2006). Standar Isi Untuk Acuan Pendidikan Dasar dan Menengah. Jakarta: BSNP.

Budiarti, V., Syafitri, Y. D. T., \& Derin, T. (2019). An Article Review on "Reading Comprehension Strategy Instruction in a First-Year Course: An Instructor's Self-Study". Elsya : Journal of English Language Studies, 1(1), 16-21. https://doi.org/10.31849/elsya.v1i1.2543

Cambridge Advanced Learner's Dictionary. (2000). Cambridge Advanced Learner's Dictionary (10th ed.). London: Cambridge Press.

Danim, S. (2004). Motivasi kepemimpinan dan efektivitas kelompok. Jakarta: Rineka Cipta.

Edam, N. S., Pangemanan, S., \& Kairupan, J. (2018). Efektivitas Program Cerdas Command Center Sebagai Media Informasi Masyarakat Dalam Rangka Pelayanan Publik (Studi Di Kantor Walikota Manado). JURNAL EKSEKUTIF, 1(1).

Freeborn, D. (1998). From Old English to Standard English: A course book in language variation across time. University of Ottawa Press.

Hutchinson, T., \& Waters, A. (1987). English for specific purposes. Cambridge university press.

Indrawati, D. AN ANALYSIS OF THE ENGLISH COURSE BOOK ENTITLED.
Irambona, A., \& Kumaidi, K. (2015). The effectiveness of English teaching program in senior high school: A case study. REiD (Research and Evaluation in Education), 1(2), 114-128.

Muhson, A. (2010). Pengembangan media pembelajaran berbasis teknologi informasi. Jurnal Pendidikan Akuntansi Indonesia, 8(2).

Nuh, M. (2013). The future of this nation depends on the new curriculum. The Jakarta Post. Retrieved

From:http://www.thejakartapost.com/news/2013/0 2/19/future-indonesia- depends-new-curriculumminister.html.

Richards, J. C (2001) Curriculum Development in Language Teaching. Singapore: Cambridge University Press.

Richards, J. C. (2017). Curriculum approaches in language teaching. Handbook of research in second language teaching and learning, 3, 117-131.

Sari, I. E. (2018). Effectivitas Penerapan Model Realistic Mathematic Education (RME) Dengan Menggunakan Alat Peraga Terhadap Prestasi Belajar Materi Kubus Dan Balok Pada Peserta Didik Kelas VIII Di SMP Negeri Maros. Skripsi. Tidak diterbitkan. Maros: Universitas Muslim Maros

Tomlinson, B. (2008). English Language Learning Materials: A Critical Review. New York: Continum International Publishing Group.

Wardani, W. (2010). Analisis Teks Buku Sekolah Elektronik (BSE) IPS Terpadu Kelas VII SMP/MTs Terbitan Depdiknas pada Kompetensi Dasar Mendiskripsikan Gejala Atmosfer dan Hidrosfer Serta Pengaruhnya Bagi Kehidupan. SKRIPSI Jurusan Geografi-Fakultas Ilmu Sosial UM. 